\title{
Genetics and the Social Science Explanation of Individual Outcomes ${ }^{1}$
}

\author{
Jeremy Freese \\ Northwestern University
}

Accumulating evidence from behavioral genetics suggests that the vast majority of individual-level outcomes of abiding sociological interest are genetically influenced to a substantial degree. This raises the question of the place of genetics in social science explanations. Genomic causation is described from a counterfactualist perspective, which makes its complexity plain and highlights the distinction between identifying causes and substantiating explanations. For explanation, genomic causes must be understood as strictly mediated by the body. One implication is that the challenge of behavioral genetics for sociology is much more a challenge from psychology than biology, and a main role for genetics is as a placeholder for ignorance of more proximate influences of psychological and other embodied variation. Social scientists should not take this challenge from psychology as suggesting any especially fundamental explanatory place for either it or genetics, but the contingent importance of genetic and psychological characteristics is itself available for sociological investigation.

Consider some titles retrieved by searching a library's catalog for who*:

Who Votes?

Who Gets Ahead?

Who Commits Crimes?

Who Goes to College?

\footnotetext{
${ }^{1}$ This article has benefited from comments from participants in colloquia at Brigham Young University, Columbia University, and the University of California at Los Angeles. I thank also Matt Bradshaw, Daniel Fessler, Bob Hauser, Mark Hayward, Brayden King, Jui-Chung Allen Li, Rob Mare, John Levi Martin, Ed McCabe, Aaron Panofsky, Brian Powell, Mike Shanahan, and Norton Wise for provocative queries and helpful suggestions. I am grateful for support from the Robert Wood Johnson Scholars in Health Policy Research Program. Direct correspondence to Jeremy Freese, Department of Sociology, Northwestern University, 1810 Chicago Avenue, Evanston, Illinois 60208. E-mail: jfreese@northwestern.edu
}

(C) 2008 by The University of Chicago. All rights reserved.

0002-9602/2008/114suppl-0001 $\$ 10.00$ 
American Journal of Sociology

Who Marries Whom?

Who Is Happy?

Who Reads Literature?

Who Dies?

Descriptive answers to "Who $y$ ?" can be obtained by simply cross-tabulating $y$ (voting, getting ahead) by whatever categories one finds interesting (gender, ethnicity, education). In contrast, explanatory answers to "Who $y$ ?" involve articulating and substantiating why specific characteristics are implicated in individuals' realization (or not) of $y$. That more highly educated people are more likely to vote is part of the descriptive answer to Who votes? The explanatory answer demands a narrative account of why this is so, a narrative that, if education is causal, takes us continuously from immediate consequence(s) of education to immediate cause(s) of voting. Such narratives often, in turn, highlight as matters for further explanation the biographical development of causally relevant attributes of individuals and the historical development of why they are relevant: why some people are more educated than others and why we have the current system of voting as opposed to some alternative for which the causal import of education for voting may be different (e.g., legally mandated voting). Ultimately, just as a persistent child can follow answers to why questions with more why questions in myriad directions until the parent is either exhausted or stumped, explanations of why some people $y$ and others do not are bounded by practicality and answerability.

Social scientists typically regard explanation as central to their enterprise. Increasingly, there has been interest in better reckoning with the relevance of genetic differences for explaining individual outcomes of long-standing social science concern. Over the last several decades, behavioral genetics studies have reported nontrivial heritabilities for a vast array of psychological traits, attitudes, behaviors, and attainments (Udry 1995; Plomin et al. 2001; Alford, Funk, and Hibbing 2005). That studies in behavioral genetics have reported some heritability for nearly everything subjected to their gaze has led to a declared conclusion that "the bottom line is everything is heritable. . . . The empirical facts are in and no longer a matter of serious controversy" (Turkheimer 2000, p. 160). I call this the ubiquitous partial heritability thesis: that is, genetic differences are partial causes of the overwhelming majority of individual-level outcomes of interest to psychological and social science. Most work supporting this thesis has proceeded without direct measurement of genes, relying instead on twin and other family data for which the underlying statistical assumptions have been long criticized (e.g., Lewontin 1974; Goldberger 1979). As argued below, however, even as these assumptions give reason to doubt the precision and interpretation of reported herita- 
bility estimates, available evidence sustains the upshot that genetic differences matter pervasively for how individual biographies unfold.

While sociologists vary enormously in their opinions about what sociology is, two observations follow from surveying the quantitative studies published in the American Journal of Sociology over the last 30 years. More than half examine individuals as the unit of analysis of the primary outcome, and very few give consideration of-especially either positive or genuinely serious consideration of-genes as causes of observed variation in the outcome. Sociologists commonly conceptualize their role in studying individual outcomes as that of emphasizing a particular content in explanations, namely, the importance of causes ("factors," "forces") understood as "social." Sociological explanations are cast as standing opposed to various kinds of not-sociological explanations, with perhaps none more opposed than genetic explanations. The disciplinary boundary excluding genetic causation - accompanied perhaps by a generalized suspicion about whether behavioral genetics studies really have any merit—continues to justify silence about genes as causes, even in the sense of being entertained as possible confounders in studies for which the ubiquitous partial heritability thesis implies clearly untenable inferences.

The inattention to genetic causes by sociologists interested in individual outcomes is likely to face increasing challenge, for several reasons. First, increased availability of data with genetically informed designs and increased integration of DNA into large-scale social science data sets both undermine the pseudopragmatic rationale that genetic causation may be ignored because it cannot be properly addressed. Second, enthusiasm for genetics among important sources of research funding (e.g., Sankar et al. 2004) indicates that external incentives for collecting and working with genotypic information are strong. Third, increasing cognizance of the vulnerability of familiar analysis strategies to biases from unobserved heterogeneity means that even researchers resolute in having an exclusive interest in "social factors" may be expected to defend estimates against genetic confounding, especially if they seek results that can withstand scrutiny by extradisciplinary audiences. Finally, enthusiasm for geneenvironment interactions, accompanied by new studies that have been taken as provocative harbingers of what lies ahead (esp. Caspi et al. 2002, 2003), may obsolesce traditional disciplinary boundaries and privilege work that seeks to make connections across disparate kinds of causes. In sum, while as sociologists we may be able to determine the place of genetics in sociology, we do not control the place of genetics in public and the overall scientific understanding of the problems we study, nor do we control the place of sociology as a consulted authority in contributing to that understanding.

There is thus much cause for worry for sociologists who identify the 
American Journal of Sociology

discipline with causes "outside the body" and see it as involved in a zerosum battle of "competing explanations" with causes "inside the body" (Duster 2006). Some propose that the main way sociologists should engage behavioral genetics is through critical, detailed studies of its practices in ways oriented toward undermining its conclusions (Duster 2006). However important such work may be to certain highly charged areas where the potential for pernicious naïveté about genetics is especially high (i.e., race), we might regard its prospects as more limited for serving as the dominant approach of sociology to research on genetic causes of human outcomes, especially if the main intention really is just attempted debunking.

I seek here to stake out a different view. I grant the premise that behavioral geneticists are (roughly) correct in concluding that virtually every outcome sociologists have cared to study about individuals is genetically "heritable" to a nontrivial degree. I grant that we have every reason to expect the future of social research to include a shower of stars denoting statistically significant "effects" of genes and gene-environment interactions on individual outcomes and that many of the findings will reflect real causal relationships between genes and these outcomes. If these premises turn out to be wrong, so much the easier for entrenched ways of thinking in sociology. Otherwise, while these developments might require some revision of conclusions about the empirical world with which some of us began graduate school, I deny that these developments undermine the raison d'etre of a discipline deserving of a name as ambitious as sociology. Indeed, existing discourse indicates all too clearly that the increased presence of a sociological imagination is sorely needed to help understand what the accumulated insights of behavioral genetics studies mean for explaining the varying fates of individuals acting and being acted upon in societies.

I begin by discussing genes as causes, their interpretation within a counterfactual perspective on causality, and the difference between estimating causal effects of genes and determining how they figure into explanations. Then, I argue that even though questions about the causal effects of genes can be clearly posed, the explanatory value of the answers for social science is complicated by what I call the phenotypic bottleneck that genes cause behavior and subsequent outcomes (almost) exclusively via their effects on the material constitution of actors. The phenotypic bottleneck is crucial to understanding when and how genetic causation is consequential to meaningful explanation of individual action and outcomes. In describing how, I show that the seeming threat of genetics to sociology masks simultaneously a pervasive problem of social theory, an underdeveloped conceptualization of actor psychology, and a pervasive problem of research method-that is, an overdependence on a regression- 
friendly perspective on how human lives unfold. The model of genes in explanations I develop calls attention to a set of questions about the societal generation of genetic consequences that are largely unexplored. I conclude by summarizing constructive lines of inquiry consistent with a world where "everything is heritable," for ubiquitous heritability poses challenges that sociologists can productively engage in many ways other than minimization and denial.

\section{GENES AS CAUSES OF INDIVIDUAL OUTCOMES}

Abbott (2001, pp. 293; 2005) invites readers to imagine orthodox causal analysis in sociology as operating upon a data space of variables that change over time, one of which is privileged by the observer as the "outcome," while some others are invoked as causes. If we look at the specific individual-level variables that have served as outcomes in the $A J S$, they permit a rough, heuristic division that will prove useful for thinking about genes as causes and as parts of explanations. First are actions, whether interesting in single occurrences (e.g., vote choice [Manza and Brooks 1998], first intercourse [Bearman and Bruckner 2001]) or as a recurrent pattern over time (e.g., parental investment in children [Freese and Powell 1999], political participation [Antunes and Gaitz 1975]). Second are actors' internal states, which are often regarded as interesting for what they are taken to imply for action (thinking about divorce [Huber and Spitze 1980]) or about the causality of sociocultural forces (social attitudes [DiMaggio, Evans, and Bryson 1996], perceptions of crime rates [Quillian and Pager 2001]), but sometimes are taken as an end in themselves (alienation [Kohn 1976], job satisfaction [Gruenberg 1980]). Third are aspects of actors' circumstances, which often invite interpretation as the result of iterations of individual actions and social response (educational attainment, occupational attainment, and earnings, which have been the most commonly studied individual-level outcomes over the past 30 years).

The thesis of ubiquitous partial heritability is that genes are causally related to the overwhelming majority of the individual-level variables studied as outcomes by social scientists, which I will hereafter call "individual outcomes" and intend as defined ostensively by the above examples. What it means to say that genes are ubiquitously causally related to individual outcomes may seem immediately obscure given that, as a proximate matter, "all genes do" is provide instructions for building proteins. However, this fact of proximate causation is not inconsistent with ubiquitous partial heritability, at least as interpreted in the terms of the counterfactual approaches to causality that have become prominent in quantitative social science (Morgan and Winship 2007; Heckman 2005). 


\section{American Journal of Sociology}

I begin here by presenting a counterfactualist interpretation of the meaning(s) of claims of genetic influence on individual outcomes. While abbreviated and by necessity somewhat stylized, the explication will make plain the key problem of reconciling genes as causes and as parts of explanations in social science: evidence can indicate that genes have large effects while the pathways by which those effects are produced may be highly multiple, distal, complex, and, at least given current knowledge, mysterious. The discussion will also provide some orienting observations about genes and environments as causes that will be important later.

Counterfactual perspectives on causality in social science are often credited with changing amorphous, difficult-to-approach questions about causes to more clearly posed ones (Holland 1986; Morgan and Winship 2007). The question "Who $y$ ?" is first transformed to "What is the effect of $x$ on $y$ ?" where $x$ is a specific candidate causal variable. That question, in turn, is answered by reference to hypothetical reassignments of $x$ at some pertinent point in the past and comparing the observed $y$ given actual $x$ to informed expectations about the $y$ that would have been observed had the counterfactual reassignment of $x$ occurred instead. ${ }^{2}$ The causal effect of $x$ is always expressed relative to alternatives: the effect of attending college, for instance, is more explicitly the effect of attending college versus finishing high school but then not attending college.

If we use $x^{a}$ and $y^{a}$ to refer to the actual, observed values of $x$ and $y, x^{\mathrm{a}}$ to the desired comparison value of $x$, and $y^{\mathrm{c}}$ to the value of the outcome if $x$ had been reassigned to $x^{\mathrm{c}}$ instead of $x^{\mathrm{a}}$ at the pertinent point in the past, then the causal effect of the change from $x^{\mathrm{c}}$ to $x^{\mathrm{a}}$ is $y^{a}-y^{c}$. In other words, the causal effect is defined by our estimate of how the outcome would be different if the causal variable had been different. In observational studies, evidence supporting particular estimates of $y^{\mathrm{c}}$ under counterfactual $x^{\mathrm{c}}$ are typically derived either from otherwise similar entities for which $x^{\mathrm{c}}$ was observed (as in analyses of cross-sectional data) or from the same entity at other times in which $x$ differed from $x^{\text {a }}$ (as in analyses of panel data).

Consider $\mathbf{G}_{i}$ to comprise the genome of person $i$ at biographical time $t=0$ (i.e., "conception") with originating environment $\mathbf{E}_{i, t=0}$. Under the counterfactualist perspective, two quite distinct families of individuallevel "genetic effects" may be defined. First, I use specific gene effect to refer to the consequence for $y$ of the reassignment at $t=0$ of some particular element or small configuration of elements $g$ of $\mathbf{G}_{i}$ from their actual

\footnotetext{
${ }^{2}$ Discussion here is not intended as a substitute for a full-fledged philosophy of causality. For philosophical discussions of counterfactual perspectives on causality broadly compatible with the simplified discussion here, see Woodward (2003) and Collins, Hall, and Paul (2004).
} 
state $g_{i}^{\text {a }}$ to some alternative element or configuration $g_{i}^{\mathrm{c}}$. That is, a specific gene effect refers to how $y$ would be different if some particular portion of the genome were different, but the rest of $\mathbf{G}_{i}$ and the originating environment were the same. The specific gene effects of interest are presumably those that reflect the change of specific genes to alternatives (alleles) that other people actually have.

Second, I use whole genome effect to refer to the wholesale change of $\mathbf{G}^{\text {a }}$ to some alternative $\mathbf{G}^{\mathrm{c}}$ - the idea that, under $\mathbf{E}_{i, t=0}$, a different $\mathbf{G}$ was assigned to $i$. The ubiquitous partial heritability thesis concerns whole genome effects, and so accordingly these will be the focus of most of this article. However, much recent enthusiasm about genetics and social behavior has focused on the integration of genotypic (DNA) information into large-scale studies for the purposes of estimating specific gene effects. It is widely thought that whole genome effects for complex psychological traits-and, by implication, the behaviors and behavioral consequences these traits influence-typically involve action and interaction among many genes (Plomin, Owen, and McGuffin 1994). Specific gene effects will then be expected to be small relative to whole genome effects. Human molecular behavioral genetics has been beset by replication failures, partly due to the presumed smallness of many specific gene effects and the problems of significance testing when one can analyze associations multiple genes by multiple outcomes by multiple subgroups (Balaban 2001). In contrast, the contemporary ecology of large social surveys is such that many offer unique opportunities in terms of some combination of size, content, and population. One might therefore urge particular caution for findings of specific gene effects-or gene-environment interactions-when questions are posed of data that are unique with respect to that question and thus offer no opportunity for replication anytime soon (e.g., some questions that might be asked of AddHealth). A cautionary tale is provided by one of the studies that has brought much recent attention to gene-environment interactions, which has since had a mixed replication record (Caspi, McClay, et al. 2002; see summary by Morris et al. 2007). On the bright side, accumulating studies about specific genes allow studies to proceed in an increasingly informed way, especially regarding geneenvironment interactions (Moffitt, Caspi, and Rutter 2005; Shanahan and Hofer 2005).

Obvious candidate counterfactuals for whole genome effects are genomes of others in the population-as if, at $t=0$, the individual's genome was swapped for a copy of the genome of someone else. The genomic effect for an individual compares $y^{a}$ given actual $\mathbf{G}_{i}^{\mathrm{a}}, \mathbf{E}_{i, t=0}$ to the expected $y$ given $\mathbf{E}_{i, t=0}$ and a random draw from all $\mathbf{G}$ in some population. Genomes may matter much more in some originating environments than others, as reflected in arguments that poor environments thwart the so-called genetic 
American Journal of Sociology

potential of actors and thus attenuate genomic effects much more than richer environments do (Guo and Stearns 2002; Turkheimer et al. 2003). Also, a genome that yields a better outcome in one originating environment might yield a worse outcome in another (Lewontin 1974; Freese 2006). In other words, even just for one specific outcome, there is no transcendent concept of the superiority of one genetic endowment over another.

I fully recognize the fanciful character of talking about swapping a person's genome for someone else's, but that such manipulations cannot actually be done should not preclude us from thinking in these terms if it corresponds to a clear conceptualization of what is asserted in saying that something is in part genetically caused. The assertion is that expectations about the outcome would be different had the genome had been different and everything else (i.e., the originating environment) been the same. Notice also that the assertion implies nothing about what specific gene effects are responsible for the whole genome effect.

Some concept of "originating environment" is needed for counterfactualist interpretation because a crucial aspect of genomic causation is that individuals affect subsequent environments. Actors influence their circumstances, and to whatever extent genetics is causally implicated in that influence, genetics is causally implicated in its consequences for future environments and the consequences of those environments for future behaviors. If genetic differences are partial causes of height (Macgregor et al. 2006), and height is a partial cause of attractiveness (Ellis 1992), and attractiveness is a partial cause of positive interactions with others (Snyder, Tanke, and Berscheid 1977), and positive interactions are a partial cause of self-esteem (Wylie 1979), and self-esteem is a partial cause of delayed first intercourse (Meier 2007), then age at first intercourse is genetically influenced, even if only via this path. ${ }^{3}$ This points to an immediate problem with questions pitched at the level of how much of some outcome "is genetic" and how much "is environmental," because genetic differences can be causes of environmental causes (and, as discussed later, vice versa).

To put this more precisely, I use $\mathbf{P}_{i}$ to refer to the phenotypic characteristics of person $i$. As considered more shortly, I intend "phenotype" in the relatively restrictive sense of characteristics that are embodied-that is, materially realized as part of the organism. So a person's height, personality, and skills are part of $\mathbf{P}_{i}$, but their earnings, marital status, and spouse's educational attainment are not. The total effect of the whole

\footnotetext{
${ }^{3}$ If this was the whole story, one would expect effects of genes implicated in height to be consistently attenuated with each successive step of the narrative, as I discuss later.
} 
genome includes all the causal paths from $\mathbf{G}_{i} \rightarrow \mathbf{P}_{i} \rightarrow \mathbf{E}_{i} \rightarrow y_{i}$, including whatever complicated chains of sequences might unfold over time of environment effects on phenotype $\left(\mathbf{E}_{i} \rightarrow \mathbf{P}_{i}\right)$ and phenotype effects on environments $\left(\mathbf{P}_{i} \rightarrow \mathbf{E}_{i}\right)$. Such relationships are referred to as "gene-environment correlations," but this is misleading for causal interpretation, as genes are here distal causes of more proximate environmental causes. ${ }^{4}$ The question of how much population variation in $y$ "is genetic" versus how much "is environment" only has a coherent interpretation if genes do not affect environments (no $\mathbf{G} \rightarrow \mathbf{P} \rightarrow \mathbf{E}$ ), or if the environmental characteristics affected by genes do not affect the outcome (no $\mathbf{E} \rightarrow y$ for any elements of $\mathbf{E}$ for which $\mathbf{G} \rightarrow \mathbf{P} \rightarrow \mathbf{E}$ ).

Heritability estimates from behavioral genetics are commonly presented as partitioning observed variation in $y$ into that explained by genetic versus environmental variation. If genes influence environments, then this partitioning is actually genetic versus exogenous environmental variation-environmental differences not at all caused by genetic differences. Even that interpretation is problematized if we imagine that genetic differences moderate the effects of exogenous environmental causes (geneenvironment interactions). Even so, under a broad range of conditions, nonzero heritability estimates imply nonzero average whole genome effects in a population, and qualitative assessments of heritability are not obviously unreasonable general characterizations of average whole genome effects for a population, especially for comparisons of the relative size of effects across outcomes.

Heritability estimates in traditional behavioral genetics studies are derived from the relationship between outcome similarity of individuals and the (assumed) similarity of their genotypes and their exogenous environments (for one highly accessible introduction, see Schaffner [2006]; for critiques, see Wahlsten [1990] and Freese, Li, and Wade [2003]). Twin studies take advantage of the natural experiment of separate individuals with identical G, comparing identical (MZ) twins to fraternal (DZ) twins. Studies typically assume no assortative mating on the trait in question. That assumption is easily questioned, but the consequence of its violation is underestimation of "true" heritabilities (Plomin et al. 2001, p. 170). Consequently, critiques of this assumption provide no comfort for those who want to believe that genes have no causal effect on traits that have been found to have substantial heritabilities in twin studies.

${ }^{4}$ Gene-environment correlations are commonly divided into three types (Plomin et al. 1977). Two, reactive (genetic influences on environment response) and active (genetic influences on environment selection) are distal causes of potential proximate causes. The other, passive correlations, imply spuriousness, not distal causation. Passive correlations include instances in which children's genes correlate with environments due to parents' genes influencing parents' behavior. 


\section{American Journal of Sociology}

Twin studies, however, also assume that exogenous environments for twins are no more similar for MZ than for DZ twins. Violations of this "equal environments assumption" (EEA) imply that estimated heritabilities overestimate true heritabilities. ${ }^{5}$ The EEA provides the most principled grounds for radical doubt regarding twin studies, but various means of indirect assessment-for example, by studying DZ twins mistakenly believed by their families to be MZ-provide no empirical grounds to think violation of the assumption is commonly anywhere near enough to nullify findings of substantial heritability (e.g., Kendler et al. 1993; Hettema, Neale, and Kendler 1995; Bradshaw 2007). Designs not involving twins have also not revealed radically divergent findings (Plomin et al. 2001). Consequently, it is hard to defend any generalized conclusion that violations of model assumptions provide grounds for concluding that substantial heritability estimates are uninformative for whether nontrivial average genomic effects exist. Problems with precision do not imply problems with upshot, especially for the binary question of Do genetic differences matter? for an outcome.

Table 1 presents a list of individual characteristics for which substantial heritabilities have been reported (at least .25 in one study). The list includes outcomes central to social stratification like educational attainment, occupational attainment, and earnings, and important demographic outcomes like age at first sex, number of children, and divorce. Some of these outcomes (e.g., educational attainment) are known to be causally influential for others (e.g., earnings, Card [1999]). Some psychological characteristics listed may be causally influential for numerous outcomes (e.g., cognitive ability [Sewell and Hauser 1975]). The total whole genome effect encompasses all paths: $\mathbf{G} \rightarrow \ldots \rightarrow y$. While a collection of 50 outcomes is not itself "ubiquitousness," the expectation is that any individual social outcome substantially causally affected by combinations of outcomes in table 1 will be nontrivially genetically caused itself. If one grants evidence that basic psychological characteristics and socioeconomic conditions are substantially heritable, at least under the current sociohistorical conditions of our population, then the ubiquitous partial heritability thesis would be satisfied merely by these characteristics and conditions mattering ubiquitously.

\footnotetext{
${ }^{5}$ At least regarding counterfactualist interpretation of the effect of genetic differences, the EEA refers to similar treatment of twins because of their status as identical twins per se and not from ways that their identicalness causes them to experience more similar environments. For example, if attractive people are treated differently, the effect of the greater similarity in attractiveness between monozygotic twins is still part of the total whole genome effect.
} 


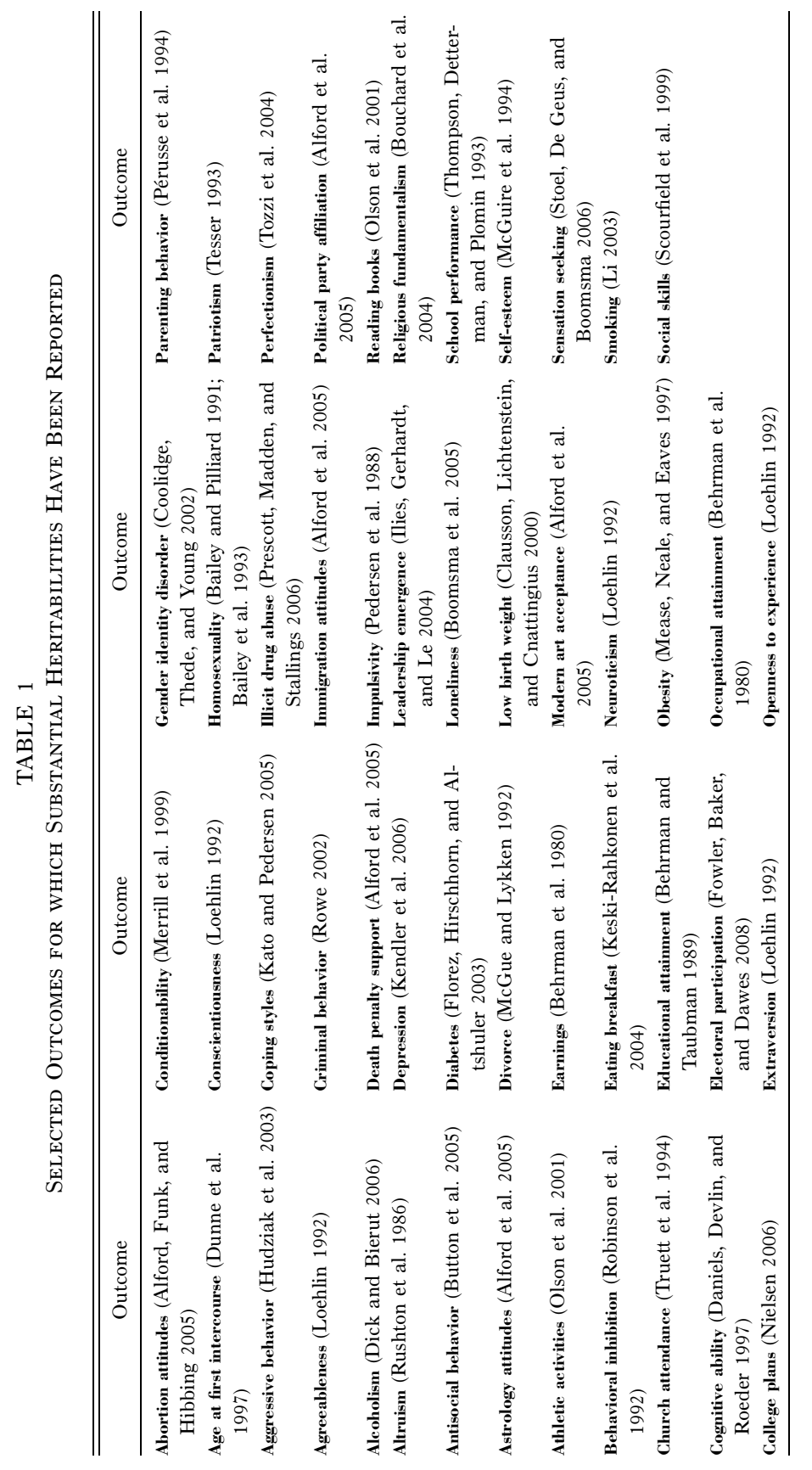


American Journal of Sociology

THE PHENOTYPIC BOTTLENECK

Knowledge that something has a causal effect makes it easy to confuse the task of explaining Why do genes affect $y$ ? with the task of explaining $y$; that is, of providing a logically continuous account of why $y$ differs for different people. We may be interested specifically in why genes affect $y$, but, alternatively, we might be interested specifically in forming an understanding of the determination of $y$ adequate for some purpose. As a cause of $y$, genes must fit into "full" explanations somewhere, as a full explanation would seem like it must broaden or deepen to include all causes somehow. But knowledge that genes cause $y$ does not make clear how this causal relationship fits into an explanation of $y$.

The problem is nothing specific to genes: numerous sociologists have complained about a deep disconnect between developing sociological explanations and conducting sociological research (e.g., Coleman 1986; Hedström and Swedberg 1998; Abbott 2001). Holland (1986) argues that researchers should concentrate on understanding the various effects of particular causes - rather than identifying the various causes of particular outcomes-precisely because questions regarding the former are more clearly posed and more easily approached from statistical vantage. Explanation, however, is as much about arranging causes as about identifying them, figuring out the syntax of an account that allows causes of different ontologies and temporalities to fit together. When, precisely, do genetics enter into explanations of individual outcomes?

This is not the place for a full philosophy of social science explanation, but one might imagine explanations abstractly as looking something like a network, with nodes being the nouns of explanation (events, states, "variables") and directed edges being the verbs (how cause-effect relations between nodes are produced, "processes," "whys"; see Bearman and Stovel [2000] on narrative networks, Hall [2004] on causal production, and Machamer, Darden, and Craver [2000] on mechanisms). The outcome is the terminal node of this network, with entering directed edges from its immediate causes. Nodes and edges then connect immediate causes to their own causes, and the causes of those causes, and so on. For explaining individual outcomes, movement from the outcome extends outward in four directions: into the actor's body, out into the social milieu of action (including relations with others), back into the biographical development of the actor, and back into the historical development of the social milieu. Under this view, genomes intrude into explanations when they become a relevant outward move in this network, which is when genomes become relevant as an immediate cause of some more immediate cause.

Here, genes have a simpler answer than many of the causes social scientists are used to working with, for which even immediate conse- 
quences invoke very different ontologies. Education, for example, has among its immediate consequences the psychological consequences of schooling, the network consequences of being in school, and the signaling consequences of acquired credentials. The immediate consequences of genes are much more crisply defined: the causal effects of genes are in the first instance causal effects upon the material body.

Consider $\mathbf{P}_{i}$ to refer to embodied characteristics of person $i$. Consistent with the preceding definition of phenotype, embodied characteristics are meant to refer to characteristics of the material constitution of actorsfor example, their psychological characteristics-as distinct from characteristics that we observe as "theirs" but are not part of their materiality. In the case of education, psychological effects of schooling experiences are effects on $\mathbf{P}_{i}$, while social network ties and educational degrees are part of $\mathbf{E}_{i}$. I use embodied here to keep the material foundations of psychology in view, and to reinforce the conceptual distinction between them and characteristics of circumstances which I treat as characteristics of environments $\left(\mathbf{E}_{i, t}\right)$.

Genomes figure in explanations of individual outcomes as distal causes of more immediate causes of $\mathbf{P}_{i}$. In the parlance of path analysis, genomes are never direct effects of individual outcomes but instead are always indirect effects that run somehow through some aspect of the phenotype. I call this the phenotypic bottleneck: the strict mediation of genetic causes by the phenotype. The phenotypic bottleneck may seem obvious, but it has less obvious implications, as we shall see. Moreover, discourse about genes and social outcomes evinces a common tendency to proceed from genes to distal outcomes without recognizing the substantive implications of thinking through the intervening phenotype. One recent sociological example is Nielsen's (2006) argument that heritability estimates can be used to judge the "opportunity for achievement" afforded by a society without knowing any details about the specific phenotypic characteristics that matter for achievement and how. Nielsen reasons that heritabilities of attainments would be minimized in societies in which attainments were determined exclusively by family standing, so societies with higher heritabilities for attainments are societies with greater opportunity. The conclusion is erroneous because social selection can proceed on heritable phenotypic characteristics whose causal influence we would not characterize as "opportunity for achievement" or "realization of native potential" (Nielsen 2006, p. 207), as in the case of discrimination among nonwhites based on darkness of skin color (e.g., Hersch 2006). ${ }^{6}$ An important part

${ }^{6}$ Garfinkel (1981, pp. 119-20) observes that heritable traits may be subjected to social discrimination and argues that in such cases discrimination is "the" real cause of the resulting outcome and genes are not. My interpretation, by contrast, is that genes and 
American Journal of Sociology

of the sociological response to behavioral genetics should be insistence on the fundamental importance of explicating the intervening embodied paths from genes to outcomes.

The phenotypic bottleneck implies that genes obtrude into social explanations in two different ways. First, they enter at some point into the explanation of why $\mathbf{P}_{i}$ is as it is or why $\mathbf{P}_{i}$ has changed as it has. What is meant by "at some point" will be considered shortly. Second, unresolved causal effects of genomes serve as a placeholder, indicating our lack of understanding of what about the phenotype (or earlier effects of the phenotype upon the environment) is responsible for the unresolved effects. That substantial genetic effects on outcomes are not well understood by our existing apparatus of social explanation is not a vague victory for "biology" over "sociology" but a broad call for social theory to develop a more sophisticated understanding of how individual characteristics are implicated in presumedly myriad ways in determining individual fates. Indeed, as the next sections will argue, the challenge posed by findings of substantial whole genome effects is really less a challenge from biology as it is from psychology.

\section{GENETICS AND SOCIAL CAUSES}

This section provides a more precise consideration of what the phenotypic bottleneck implies for when genes becomes relevant in explaining individual outcomes, with particular reference to "stopping rules" of inquiry for social scientists exclusively interested in nongenetic causes of outcomes. I noted earlier that most individual outcomes studied by sociologists can be roughly divided into actions/action-patterns, internal states (which comprise a subset of embodied characteristics), and aspects of circumstances. Each kind of outcome, moreover, can be invoked as a possible cause in a study focused on another. Abbott's data space of variables can be divided into two spaces, one encompassing embodied characteristics of actors and one encompassing elements of external circumstances, with spaces transformed over time by actions and responses to actions, as well as exogenous events and intraindividual development. This provides a stylized generalization of various analytic approaches to social science (e.g., Coleman 1990; Hedström 2005; Elster 2007), depicted in figure 1.

In this model, immediate causes of action at any point in time are embodied characteristics of the person $\left(\mathbf{P}_{i}\right)$ and characteristics of actor's circumstances $\left(\mathbf{E}_{i}\right)$ that together define the immediate available opportunities for action. $\mathbf{W}$ is a conceptual vector intended to stand for the logic

discrimination are both real causes that stand in a particular narrative configuration with one another. 
Genetics and Social Science

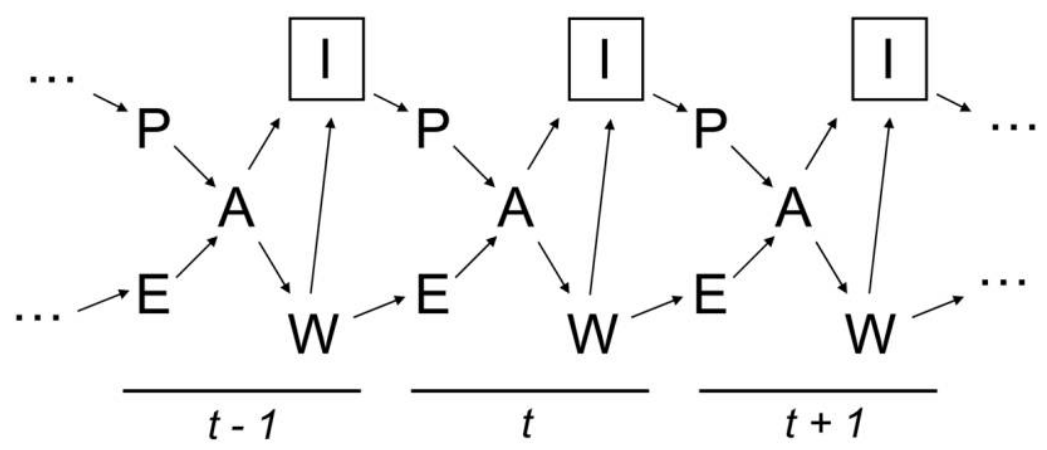

P embodied characteristics of actor
E characteristics of immediate situation/environment
A action
W logic of response of social world to action
I logic of internal response to action and external response

FIG. 1.-Basic schemata for dynamic analytic explanations of individual outcomes

of the field in which the action is conducted-including relationships to and characteristics of other actors-and implies that actions elicit a response from the world that is partly exogenous (or, in the case of the occurrence of exogenous events, $\mathbf{W}$ introduces change wholly unrelated to $\mathbf{A})$. $\mathbf{I}$ is the complementary conceptual vector intended to stand for the logic of internal response of the actor, how actions and responses to actions change the embodied characteristics of an actor over time. $\mathbf{W}$ and $\mathbf{I}$, in other words, determine the dynamic connection of $\mathbf{P}_{i, t}$ and $\mathbf{E}_{i, t}$ to $\mathbf{P}_{i, t+1}$ and $\mathbf{E}_{i, t+1}$. At any particular time (or range of times), some element of $\mathbf{A}, \mathbf{E}$, or $\mathbf{P}$ might be highlighted as the "outcome" that we seek to understand. I is in a black box in figure 1 because social science typically seeks to leave $\mathbf{I}$ as much as possible to other disciplines, while $\mathbf{W}$ is not in a black box because its operation is precisely what much of social science endeavors to understand.

$\mathbf{G}$ may figure either into the original determination of $\mathbf{P}_{i}$ (at $t=0$ or whenever the explanatory exercise takes as its starting point) or into our understanding of differences in $\mathbf{I}$ between people, that is, differences in how actions and events change actors. A common misconception is that, since genes are fixed at conception, they operate like instructions for building a wind-up doll that is then set loose into the environment where it meanders away from its genetic origins. Genes are fundamental to the material constitution of actors and part of the causal influence or genetic variation is variation in how body and mind change in response to events. 
American Journal of Sociology

Considering also that genes influence environments, it should be unsurprising that estimated heritabilities commonly increase with age, rather than dissipate (e.g., McGue et al. 1993).

If we take the model in figure 1 and add the observation that genes enter explanations as explanations of original $\mathbf{P}$ or of $\mathbf{I}$, then genes as causes in explanations of actions follow a minimal path $\mathbf{G} \rightarrow \mathbf{P} \rightarrow \mathbf{A}$ and in explanations of circumstances follow a minimal path $\mathbf{G} \rightarrow \mathbf{P} \rightarrow \mathbf{A} \rightarrow \mathbf{E}$. If we think the primary embodied characteristics important for explaining behavior are psychological-meant here to encompass all mental states and processes-then the phenotypic bottleneck implies the slogan "no biology without psychology" for explaining action. Logically continuous explanatory accounts do not proceed from genes directly to behaviors, but instead explanation demands articulable characteristics of the embodied phenotype that are partially caused by genes and partially cause the action under the given social conditions. Likewise, accounts do not proceed directly from embodied characteristics to circumstances, but instead through actions and responses to them.

Consequently, an explanatory chain connecting genetic differences to differences in social attainments must traverse three ontologically distinct questions: (1) How do a genes and environments interact to produce the embodied characteristics of the person? (2) How do embodied characteristics interact with immediate circumstances to produce actions? (3) How do actions interact with the logic of the society to produce biographical outcomes like "getting ahead"? Each question maps onto a familiar opposition of internal-external causation in social science theory: (1) genesenvironment, (2) person-situation, (3) agency-structure (see fig. 2). Each is a question of how the unfolding character of an entity reflects the inner character of the entity versus the external action of the substrate in which the unfolding occurs. Each prompts debate about which side of dichotomy is more important while at the same time provoking recognition that "of course" they continually interact: genes only develop within environments, persons only act within situations, agency is only exerted within structure. The three questions suggest the possibility of defensible division of labor in explanatory work: explaining attainments from actions and circumstances; explaining decisions and behaviors from embodied characteristics and situations; and explaining individual development from genes and environments. How continuing education affects ultimate occupational prospects may be conceptually separable from understanding how cognitive abilities affect whether one attempts and is allowed to continue education, which in turn may conceptually separable from how genes and environments affect cognitive abilities.

Although "social" causes are involved in answering all three questions, sociologists might find explaining actions and attainments as best suited 
Genetics and Social Science

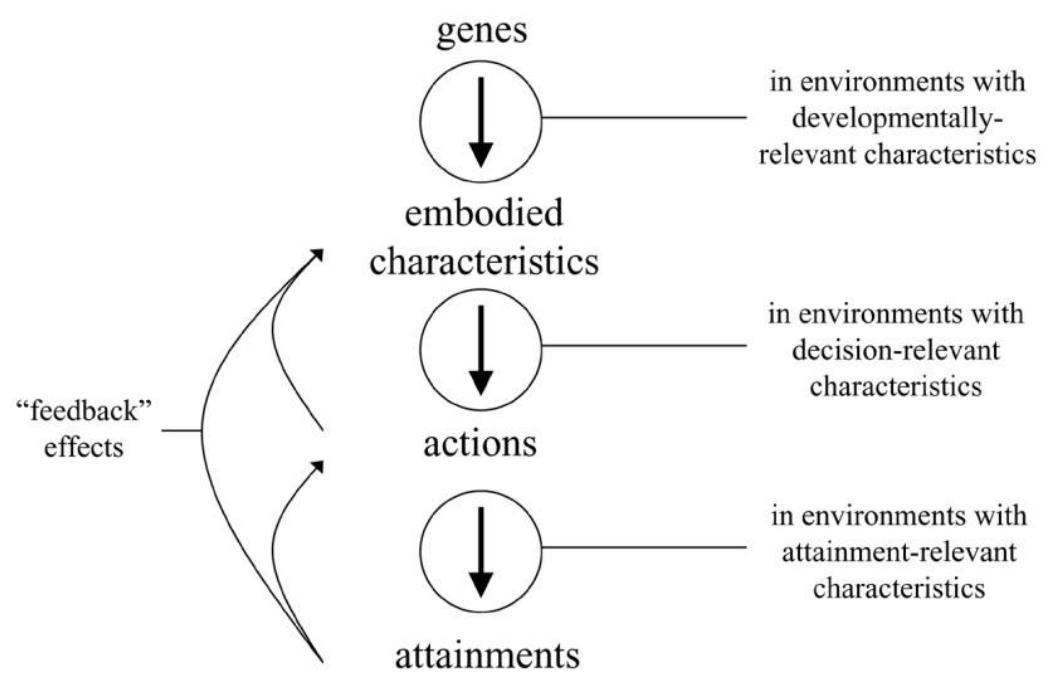

FIG. 2.-Three levels of external-internal causation from genetic differences to attainment differences.

to their expertise. Figure 2 could serve to justify a stance of disciplinary indifference toward the origins of embodied characteristics: a boundary for social explanation that does not challenge claims of behavioral genetics, but also does not require details of genomic causation in producing explanations adequate for the practical purposes of social science. The existence of substantial whole genome effects on actions and in attainments suggests that much may be gained from work that more seriously contemplates the implications of individual psychological variation, but the origins of that variation may be of less interest. In terms of explanatory "stopping rules," the origins of psychological variation may be an especially reasonable point for a sociologist to remain agnostic and pass the explanatory baton onto another discipline.

Yet, this provides only limited cover for sociologists whose response to behavioral genetics is that they are only interested in "social" causes, for genomic causes still intrude into estimating effects of social causes. As depicted in figure 3, genomic causes may stand in any of four basic relationships with social causes. Here, $y$ is the outcome of interest, $\mathbf{E}_{\mathrm{x}}$ is the social cause of interest, $\mathbf{G}$ is the genetic cause which we take as operating through its influence on embodied characteristic(s) $\mathbf{P}_{z}$. To fix ideas, consider the example in which $y$ is earnings, $\mathbf{E}_{x}$ is attending college, and $\mathbf{P}_{z}$ are abilities that are partly genetically caused. The causal question of interest is whether individuals' earnings are higher if they attend college.

Scenario $(a)$ of figure 3 is the most benign for genetically naive social 
American Journal of Sociology

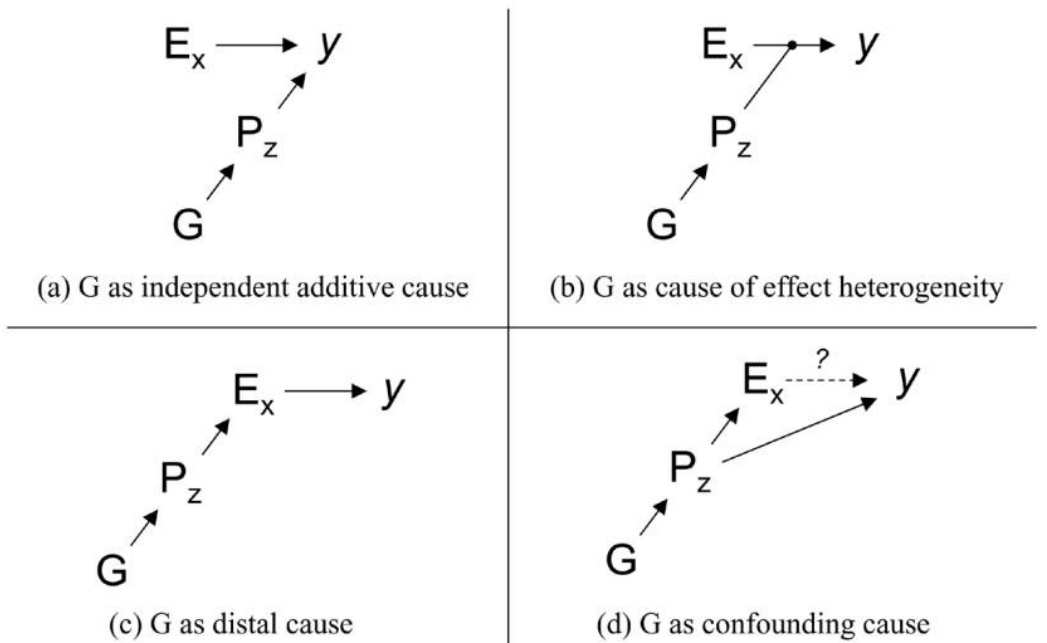

FIG. 3.-Four scenarios illustrating the relationships between genetic causes and social causes of individual outcomes.

science. Here, genetics may have a strong effect on earnings through abilities, but that effect is independent of the effect of education. Estimating the causal effect of education with abilities unobserved will leave a large amount of mysterious unexplained variation, but the effect of education is correctly estimated. In $(b)$, the effect of education varies by abilities. So long as abilities do not affect selection into education in the first place, then $\mathbf{P}_{z}$ being an unobserved cause of effect of heterogeneity does not bias estimation of the average causal effect. However, the existing educational regime benefits some who partake of it more than others, and the analyst has no leverage for understanding why. In (c), genetic differences may strongly affect earnings through abilities because abilities affect education, and abilities have no effect on earnings beyond their effect on education. While abilities remain important for anyone trying to explain why some people receive more education than others, the estimated effect of education on earnings is unbiased so long as abilities do not affect the returns to education itself. If they do (a combination of $(b)$ and $(c)$ ), the estimated effect is biased by standard methods. In $(d)$, abilities affect both education and earnings, yielding the familiar problem of spuriousness where the observed association between education and earnings is at least partly, and perhaps entirely, due to unobserved abilities.

Within this logic, the implication of ubiquitous partial heritability for estimating effects of social causes is straightforward. If one thinks that causes and outcomes are both complexly caused in ways only partly re- 
flected in the observed variables, then one should anticipate the strong possibility of pervasive unobserved heterogeneity implying possible confounding. Ubiquitous partial heritability gives reason to expect that social causes and outcomes will be genetically influenced, and the embodied characteristics responsible for this influence may overlap and thus confound causal effects if not accounted for. In other words, a researcher's default expectation should be biased estimates. One strategy against such bias is to measure and adjust for confounding embodied characteristics, which works to the extent these are fully and accurately measured and correctly specified in the analysis. If this is implausible, one can proceed by methods including (1) using individuals as their own controls in a fixed-effects longitudinal design, (2) finding natural experiments in which we can be confident the social cause is exogenous of actor characteristics (e.g., instrumental variables approaches), or (3) using genetically informed designs (Rutter et al. 2001).

Currently, many quarters of social science still practice a kind of epistemological tacit collusion, in which genetic confounding potentially poses significant problems for inference but investigators do not address it in their own work or raise it in evaluating the work of others. Such practice implies wishful assumptions if our world is one in which "everything is heritable." While particular areas might be quite productive-yielding literature that can be summarized as saying "many studies show $x$ "- they are chronically vulnerable to sweeping dismissal from outside. Nothing makes the work of imperializing academics (whether from behavioral genetics or, e.g., economics) easier that an incisive, significant, and easily explained flaw shared by an entire literature.

\section{THE PRIMACY OF EMBODIED VARIATION}

Genetics enter into explanations of individual outcomes at the point of explaining embodied characteristics of individuals. Those uninterested in origins or change in embodied characteristics can often take genetics as outside the purview of explanatory inquiry into individual outcomes, so long as they acknowledge the counterfactual dependence of outcomes on genetic variation and address the implications for confounding estimates of effects of social causes. At the same time, the accumulated findings of behavioral genetics also provide three big clues regarding how individual outcomes are determined (at least for the populations on which many behavioral genetics studies have been conducted). These are clues about the relationship between individuals and social structure, not about genetics per se, although they will figure in our subsequent discussion of genetics and explanation. 
American Journal of Sociology

1. From the thesis of ubiquitous partial heritability and the phenotypic bottleneck, one implication is that embodied characteristics matter strongly and pervasively as causes of the determination of individual outcomes. How they matter is presumably some combination of causes of immediately relevant actions and causes of selection into social and other environmental causes.

2. The schematic $\mathbf{G} \rightarrow \mathbf{P} \rightarrow \mathbf{A} \rightarrow \mathbf{E}$ may appear to imply multiplicative dilution of the effect of $\mathbf{G}$ as one moves from the effect of $\mathbf{G}$ on $\mathbf{P}$ to its effect on $\mathbf{A}$ (the seeming product of $\mathbf{G} \rightarrow \mathbf{P}$ and $\mathbf{P} \rightarrow \mathbf{A}$ and so smaller than both) to $\mathbf{E}$ (adding $\mathbf{A} \rightarrow \mathbf{E}$ and so smaller still). We might therefore think the whole genome effects should get smaller as we move from psychological traits to actions to attainments. This is not logically necessary, as $\mathbf{G}, \mathbf{P}, \mathbf{A}, \mathbf{E}$ are vectors, not scalars. More important, empirical findings have regularly reported both substantial heritabilities for attainments and substantial "direct" genetic effects on attainments in path models that include indirect effects through measured psychological characteristics (e.g., Nielsen 2006). The implication is that embodied characteristics are of renewed consequence as one moves from one kind of attainment-like outcome to another. So long as transitions are nondeterministic, like the relationship between educational attainment and occupational attainment, we should expect embodied characteristics to be consequential again, net of their effects on preceding attainments.

3. Quantitative behavioral genetics studies commonly decompose "environmental" variation into "shared" and "nonshared" components, with the "shared" environment taken to represent environmental causes from siblings' shared environments that make them more alike. As already noted, "environment" here is really exogenous environment; assigned proportions to "genetic" and "environmental" variation are rendered fundamentally incoherent by gene-environment interactions; and the "shared" and "nonshared" decomposition is misleading because measurement error in the outcome is typically counted as "nonshared." Nonetheless, a striking recurrent finding is how little variation in individual outcomes is typically resolved by the "shared [exogenous] environment" component. Some authors interpret this as implying parents have very little influence on children (e.g., Alford, Funk, and Hibbing 2005; Rowe 1994). This is misleading, partly because any influence of parental behaviors that originate as responses to children is excluded (e.g., the parent whose choice of music lessons vs. soccer practice for their child is at all influenced by the child's wishes or aptitude). More fundamentally, the result might reveal less about parental influence than about causal effect heterogeneity — not that shared experiences are unimportant but that, pervasively, similar experiences influence different people in divergent ways. In other words, the findings of behavioral 
genetics provide grounds for radical doubt of the assumption of uniform causal effects that pervades how quantitative sociologists often talk about regression findings (Abbott 2001; Turkheimer 2004).

Together, these three clues suggest that attempts to understand variation in individual outcomes like attainments will be limited and perhaps even misleading if they do not give much serious consideration to embodied variation among actors. A joke about sociology is that its first law is "some do, some don't."” The typical failure of social science to explain much variance in individual social outcomes is a longstanding point of criticism and has provided grounds for speculation about the radical extent of fundamental probabilism in these outcomes (e.g., Lieberson 1985; Goldthorpe 2000). Findings from behavioral genetics suggest that there is indeed more order in the individual-level universe than our $R^{2} \mathrm{~s}$ would suggest, but that embodied variation is vital to understanding it.

All this just reinforces our basic point that the challenge of ubiquitous partial heritability is less a challenge of biology than of psychology. Specifically, the immediate challenge is for a better accounting of systematic psychological variation in understanding why individuals act differently in ostensibly similar situations and are affected differently by ostensibly similar experiences. Work that does not take into account such variation appends to the usual tempered ambition of sociology- "theories of the middle range" - a "theory of the middle actor." Simple, uniform actors may be perfectly adequate for generating expectations about aggregate phenomena through micromechanisms (Goldthorpe 2000; Hedström 2005). Yet, increased interest in actor variation seems a likely sequel reflecting the desire for more encompassing and fine-grained understanding.

Simple, uniform actors have had their greatest run anyway in orthodox economics, with its assumptions of uniform, unchanging preferences and actions as optimal given preferences (Samuelson 1947; Stigler and Becker 1997). Sociologists traditionally look at the world and see actors who have their own beliefs, do not use optimal reasoning, are prone to all kinds of biases, are swayed by emotions, respond to how information is framed, are influenced by affiliations and identity, internalize rules, and so on (e.g., Boudon 2003; DiMaggio 1997; R. Collins 2004). Important for thinking about genetics is that the result of this added complexity seems not just a more complicated actor but a more complicated set of parameters by which actors may be said to vary. In other words, actors will vary from one another in the extent of their divergence from a standard rational actor, and they will vary differently on each of the many dimensions that they diverge. Such variations are aspects of embodied characteristics to

${ }^{7}$ I first heard this joke from John Levi Martin. 
American Journal of Sociology

be explained and all indication is that these characteristics will prove nontrivially genetically influenced.

For this reason, sociologists interested in the fates of individuals-even just how they are influenced by "social causes"-may stand to benefit from increased contemplation of the consequences of psychological heterogeneity among actors. Perhaps the greatest reward is to be gained from those psychological characteristics that are relatively basic in the sense of being coherent, general, action-oriented concepts that have implications across a broad range of human activities. Prominent candidates would be cognitive abilities (Sternberg and Kaufman 1998), general personality traits (McCrae and Costa 2003), and broad decision-making concepts like risk preference or time preference (Frederick, Loewenstein, and O'Donaghue 2002). ${ }^{8}$ Indeed, multivariate methods can attempt to resolve some part of the heritability of distal outcomes by proximate traits, as in the examples of relationship stability by conscientiousness (Jocklin, McGue, and Lykken 1996) or of academic achievement by general cognitive ability and conscientiousness (Luciano et al. 2006). ${ }^{9}$ With many notable exceptions, social surveys have historically been relatively stinting in their measurement of basic psychological characteristics, focusing instead on measures of past experiences and present circumstances, as well as more domain-specific psychological characteristics (e.g., attitudes on specific political issues). This has only increased the difficulties for social science to use survey resources to produce better substantiated inferences about how past experiences affect the present and may contribute to the lack of specific action-level thinking that has repeatedly frustrated some observers of sociological practice (Coleman 1986; Hedström 2005). In any case, although genetics and biological information may help in the measurement of psychological constructs, it is important to emphasize that possible uses of such biomarkers as measures should not lead us to confuse body-based concepts (the $D R D 4$ gene, dopamine production) with actionbased ones (impulsivity), as the logically continuous accounts of social explanation require the latter.

As noted, genetics enter into dynamic models of social action at the point of explaining why individuals change differently in response to similar conditions, and the third clue above is precisely that such differential change may be more the rule than exception for person-environment

\footnotetext{
${ }^{8}$ Tempering enthusiasm for risk preference and time preference are findings that the constructs often do not correlate well across domains, calling into question whether they usefully characterize real actors despite their clear, parsimonious meaning in models of hypothetical actors (Freese, in press).

${ }^{9}$ I would like to note that multivariate techniques have not received the same kind of scrutiny of assumptions as have conventional behavioral genetics models for estimating heritabilities.
} 
dynamics. Reconsidering table 1, several of the characteristics listed are abstract measures of response, including conditionability (Merrill, Steinmetz, Viken, and Rose 1999), behavioral inhibition (DiLalla, Kagan, and Reznick 1994), and emotional reactivity (Flint 2000). Again, if a phenotype may be characterized as more "conditionable" than others and this difference is used to explain differences in change, then the concept "conditionability" alone is adequate for bounded explanatory purposes. We might then want to know why some people are more conditionable than others, at which point genes obtrude as part of the explanation.

When thinking about the effect of events on people, change on any particular characteristic is a matter of direction and magnitude. Certainly, some events affect different individuals in opposite ways (as stressors may increase or decrease appetite for food). For many events, though, we imagine that any change among individuals is in one direction, with differences among actors being one of degree. For example, we might imagine a training program as having only nonnegative effects on skills, and yet the gain in skills may vary considerably across persons. Genetic differences, then, might be thought as partial causes of the stickiness of the self in response to events over time. Caspi et al. (2003) finds that stressful life events increased the likelihood of a major depressive episode for those with two copies of the short allele of the 5-HTT gene but did not significantly affect the likelihood for those with two copies of the long allele. Some kinds of stickiness are good (psychological resiliency) while others are bad (difficulty in learning). Key to developing dynamic analytic social explanations that appreciate individual variation is to articulate useful concepts of actor stickiness on different characteristics and in response to different environmental causes.

\section{SOCIAL CAUSES OF GENOMIC CAUSES}

Gene-environment interactions have inspired much recent enthusiasm among social scientists (F. Collins 2004; Johnston and Edwards 2002). Gene-environment interactions imply that the same environmental cause has different effects for individuals who differ in key elements of $\mathbf{G}$. As just discussed, the possible pervasiveness of gene-environment interactions suggests that genetic differences may commonly intrude into explanations specifically in trying to understand why some individuals seem to be more influenced by particular environmental causes than others. Even so, to emphasize a main argument of this article, just because varying response may be partly caused by genetic differences does not mean genetic differences provide the most instructive terms for social science explanation. The premise of many targeted educational interventions (e.g., 
American Journal of Sociology

"alternative" schooling, programs for "gifted" students) is precisely that effects of such programs will be greater for some students than others, but this differential benefit is more informatively characterized by the putative psychological characteristics (e.g., differential benefits for those of different "learning styles" or abilities) than by whatever genetic differences partly influence these characteristics. In other words, especially for the kinds of environmental causes and outcomes of common sociological interest, many gene-environment interactions may be better characterized as phenotype-environment interactions.

Earlier I distinguished gene-environment interactions from geneenvironment correlations, in which genetic differences influence exposure to environmental causes. The logic of social systems may align the direction of gene-environment interaction and correlation in ways that amplify the association between genes and outcomes. If comparative advantage leads us to expect greater individual investment in skill domains in which one already shows aptitude-working hardest to improve at tasks one is already good at - then we would expect effective investments (e.g., "practice") to accentuate genomic differences. Children who evince early aptitude for reading also show more interest in reading and read more, which then contributes to greater subsequent differentials in reading skill (Rutter et al. 1997). When social environments encourage individuals to develop their strengths and these strengths are genetically influenced, then the main consequence of effective environmental causes may be to make the consequences of genetic differences larger. Moreover, social environments with highly differentiated opportunities might provide greater incentives favoring such investments, suggesting that sociohistorical processes that influence the importance of different kinds of comparative advantage in societies may thereby influence the importance of particular genetic differences.

The literature on person-environment "interplay" is filled with examples of accentuation, a major theme in sociological research on the life course that coincides with other social science thinking on cumulative advantage (DiPrete and Eirich 2006; Elder and O'Rand 1995; Shanahan and Hofer 2005). Individuals with greater intellectual flexibility select and are selected into environments that provide the best opportunities to improve intellectual flexibility (Kohn and Schooler 1978). Individuals with emotional instabilities select and are selected into environments that may pose the greatest risk for individuals with emotional instabilities (Rutter et al. 1997). The long-run implications of such processes are strengthening continuity within persons over time and increasing differentiation between persons (Caspi, Bem, and Elder 1989). Through fundamentally social processes, the life consequences of genetic differences contributing to the pertinent traits are widened. 
In this light, the finding of quite low heritabilities for cognitive achievement for children in relatively poor environments in the contemporary United States (Turkheimer et al. 2003) becomes especially intriguing when one considers that these environments, in absolute terms, remain superior to median developmental environments of a couple centuries ago (Clark 2007). While some have talked about genetic differences in cognitive performance reflecting an inevitable failure of "compensatory education" (Jensen 1969), one might instead consider the extent to which the contemporary influence of genes on performance has been created by the development of effective educational environments that first select on and then exacerbate cognitive differences. This is not to say that genuinely compensatory interventions cannot be developed, of course, but such interventions may require intense, concerted intervention precisely because they are "moving against the world" in the sense of narrowing differences produced within the broader operation of sociological processes that act otherwise to widen them.

When thinking about explanation as a narrative network of answers to successive why questions, genetics does not occupy any fundamental or terminal place in this network. Instead, genomic causation is itself available as a topic for explanation, and this explanation takes us back out into the social world and to processes whose explication lies squarely within sociology's jurisdiction. As the preceding examples illustrate, dynamics of social interaction and organization affect the influence of genes on outcomes. So do social policies. For instance, regardless of the cause of the genetic heritability of wealth accumulation (Behrman et al. 1980), this heritability is determined partly by the redistributive policies of a society and so these policies and their causes are part of its explanation (Fischer et al. 1996). The social causes of genomic causation are commonly black boxed by behavioral geneticists and developmental psychologists"stopping rules" that make sense given their charter-and a major negative consequence of sociological reluctance to address the genetic causes is that their social causes go black boxed or, worse, come to be seen as inevitable features of nature.

Lessons from obesity and impulsivity elaborate these points. The large increase in obesity rates in the United States cannot be explained by genetic changes in the population. Yet, obesity is substantially heritable, and, more specifically, evidence indicates that genes moderate the effect of overconsumption of calories on weight gained (Bouchard et al. 1990). There are obese adults who would not have become obese either had they been born with different genes or had they been born with the same genes a century earlier. The sociohistorical developments responsible for average increases in daily caloric consumption, as well as increases in "sedentary lifestyles," are not genetic but provide new opportunities for genomic 
American Journal of Sociology

causation. Likewise, psychological characteristics may be relevant for obesity in ways stronger than or different from earlier periods; for instance, traits contributing to impulsive eating may have been far more harmless when calories were more costly (Nederkoom, Braet, and Van Eijs 2006). Also, if motivation to prevent obesity depends on one's reference group (Christakis and Fowler 2007), traits associated with susceptibility to social influence may be newly relevant, as may be any traits associated with the composition of individuals' social networks.

Considering impulsivity, strong evidence exists of its substantial heritability (Pedersen et al. 1988), including identification of candidate genes (Kreek et al. 2005). High impulsivity has been shown to have various negative biographical consequences (Webster and Jackson 1997), and life histories of some persons with unhappy life outcomes can read like one bad impulsive decision after another (e.g., Sampson and Laub 1993). Important here are how social environments shape the consequences of impulsive tendencies. For example, strong social controls may attenuate consequences of impulsivity for teenage sexual behavior by simply circumscribing the opportunities for intercourse (Miller and Kanazawa 2001) or by raising (psychic or external) costs in ways that curb impulsivity at the margin (Dunne et al. 1997). Reproductive rights policies also affect the consequences of impulsive sexual behavior.

Somewhat differently, social policy also affects the capacity for corporate actors to take advantage of individuals' impulsivity, by offering choices that can be quickly consummated for short-term benefits with substantial probabilities of later regret (i.e., policies regulating the ease, speed and magnitude to which consumers can accumulate large amounts of debt relative to earnings). Policies that give corporate actors high freedom to create decision-making situations that derive profit from seemingly short-sighted or irrational choices are environments that heighten the importance of these psychological characteristics (and of whatever genes influence them). Sociologists recognize predatory practices as pertinent objects of social critique, but only by thinking seriously about psychological characteristics can we gain satisfactory understanding of why individuals in similar circumstances may be differentially vulnerable to various forms of consumer predation.

Ironically, increasing information about the genome provides ways for psychological variation to influence the expression of genes in ways never before possible (Freese 2006). The phenotypic bottleneck-that genetic causes must work through the body-was introduced as a matter of obvious truth, and yet it is already false in ways that may become of increasing import. When genotypic information is known, it can become the basis for action upon its expected consequences prior to any actual phenotypic expression, as the object of a deliberate, preemptive gene- 
environment interaction. ${ }^{10}$ Tay-Sachs babies used to be disproportionately Jewish but all American cases in 2006 were to non-Jewish parents, an association reversed by aggressive preemptive activity (McCabe and McCabe 2008). Phenylketoneuric babies used to always become mentally retarded, but now the implications of the disease depends on adherence to an prenatal and early childhood diet excluding phenylalynine-and such adherence appears to vary across mothers for social and psychological reasons (Widaman and Azen 2003). To the extent individual agency is implicated in the use of genetic information, genes associated with psychological traits may be newly relevant for the consequence of genes associated with health conditions. More broadly, while there is much justified concern about unfair and coercive use of DNA "profiling" (Duster 2006), we should not allow this potential for harm to preclude acknowledging that DNA information already has and will continue to bring much possibility for benefit. This, in turn, will raise important sociological questions about how variation in who benefits is determined.

\section{CONCLUSION}

Given that many regard sociology as, by definition, locked in a zero-sum struggle with "biological causes," the perceived threat to the sociological livelihood posed by the observation that "everything is heritable" is understandable. Some may have reactions similar to that of Lady Ashley upon learning of Darwin's theory: "Let's hope that it's not true, but if it is true, let's hope that it does not become widely known." Yet, all indications are that the ubiquitous partial heritability thesis is largely true, and inspection of mass-media coverage and public surveys indicate it is already well on its way to being widely known-even if it often not properly understood. This article has contended that a world where "everything is heritable" is a world with no less work for social scientists interested in individual outcomes. Nonetheless, a chief impediment to progress on this agenda may be some sociologists' belief that their professional identity requires them to approach behavioral genetics with deep skepticism and politicized distaste.

Findings from behavioral genetics also suggest that some of the paeans to probabilism that sociology has produced may underestimate the extent to which important life outcomes are systematically determined. Understanding this systematicity requires greater appreciation of the importance

${ }^{10}$ To see that this is different from genetic causation working through its phenotypic expression, consider that genetic information can be causal even when that information is false, as if someone had a preventative mastectomy after a test wrongly indicated a high genetic risk for breast cancer. 
American Journal of Sociology

of embodied variation - partly genetically influenced, partly not-for individual fates. However hip a call to understanding "genetics and social structure" may be, the route to connecting the halves of that conjunction goes through the embodied actor. Relationships between specific genes and specific outcomes will remain mysteries until we better understand how embodied variation among people contributes to divergence in lives. This work is not to be left to psychology, because the influence of psychological variation may involve massive reciprocal links between individual differences and differences in the social circumstances that shape individuals and their subsequent actions. How actions influence environments that influence psychology that influences actions offers an enduring abstract topic of investigation that is central to appreciating why genes have the strong influence on life outcomes that they do.

Behavioral genetics findings also underscore that the effects of social factors on individual outcomes likely vary considerably across persons. Social scientists often talk about "the" effect of causes-for example, of cohabitation, private schooling, parental involvement, military service, widowhood, or virginity pledges-when what are being estimated are average causal effects. While this has been long understood, it is not a point just to be acknowledged in passing, but should be our default for thinking about causality. As genomic data becomes increasingly available to social researchers, genetic differences seem likely to be ubiquitously indicated as a partial cause of individual variation in causal effects. Even in such cases, however, genetics are not an explanatory end but point to the need for some intervening characterization that makes differential stickiness intelligible in action-based terms. Genetic measures must not be allowed to substitute for explanatory concepts themselves, which must maintain a transparent narrative connection to action or response to action.

Data from genetically informed designs hold the promise to give social scientists more accurate estimates of the average effect of "social" causes and a more complete understanding of why the same cause affects different people differently. Additionally, however, a distinctly sociological imagination needs to be trained on better understanding how large-scale social developments are implicated in how much particular genetic differences matter and why. Sociologists already have developed disparate ways of considering how social environments can accentuate individual differences in social outcomes over time (e.g., DiPrete and Eirich 2006). Social changes also offer new pathways by which some kinds of genetically-influenced differences may become more relevant, a relevance that can, in turn, be blunted or magnified by social policies (see also Benjamin et al. 2007). Genomic causation is not in competition with social conditions, but a product of them. The years ahead will yield increased un- 
derstanding of the biological mechanisms of genomic causation, and sociology needs to complement this by articulating the social mechanisms that cause genetic differences to be more or less relevant. Sociologists should not feel that our enterprise is diminished by findings that genetic differences are causally related to differences in the individual outcomes we study, for sociological thinking is fundamental to explaining why.

\section{REFERENCES}

Abbott, Andrew. 2001. Time Matters: On Theory and Method. Chicago: University of Chicago Press.

. 2005. "The Idea of Outcome in U.S. Sociology." Pp. 393-426 in The Politics of Method in the Human Sciences, edited by George Steinmetz. Durham, N.C.: Duke University Press.

Alford, John, Carolyn Funk, and John R. Hibbing. 2005. "Are Political Orientations Genetically Transmitted?" American Political Science Review 99:153-67.

Antunes, George, and Charles M. Gaitz. 1975. "Ethnicity and Participation: A Study of Mexican-Americans, Blacks, and Whites." American Journal of Sociology 80: $1192-1211$.

Bailey, J. Michael, and Richard C. Pillard. 1991. "A Genetic Study of Male Sexual Orientation." Archives of General Psychiatry 48:1089-96.

Bailey, J. Michael, Richard C. Pillard, Michael C. Neale, and Yvonne Agyei. 1993. "Heritable Factors Influence Sexual Orientation in Women." Archives of General Psychiatry 50:217-23.

Balaban, Evan. 2001. "Behavior Genetics: Galen's Prophecy or Malpighi's Legacy." In Thinking about Evolution: Historical, Philosophical, and Political Perspectives, edited by R. S. Singh, C. B. Kribas, D. B. Paul, and J. Beatty. Cambridge: Cambridge University Press.

Bearman, Peter S., and Hannah Brückner. 2001. "Promising the Future: Abstinence Pledges and the Transition to First Intercourse." American Journal of Sociology 106: 859-912.

Bearman, Peter S., and Katherine Stovel. 2000. "Becoming a Nazi: Models for Narrative Networks." Poetics 27:69-90.

Behrman, Jere R., Zdenek Hrubec, Paul Taubman, and Terence J. Wales. 1980. Socioeconomic Success: A Study of the Effects of Genetic Endowments, Family Environment, and Schooling. New York: North-Holland.

Behrman, Jere R., and Paul Taubman. 1989. "Is Schooling 'Mostly in the Genes'? Nature-Nurture Decomposition Using Data on Relatives." Journal of Political Economy 97:1425-46.

Benjamin, Daniel J., Christopher F. Chabris, Edward L. Glaeser, Vilmundur Gudnason, Tamara B. Harris, David I. Laibson, Lenora Launer, and Shaun Purcell. 2007. "Biosocial Surveys." In Biosocial Surveys, edited by M. Weinstein, J. W. Vaupel, and K. W. Wachter. Washington, D.C.: National Academies Press.

Boomsma, Dorret I., Gonneke Willemsen, Conor Dolan, Louise C. Hawkley, and John T. Cacioppo. 2005. "Genetic and Environmental Contributions to Loneliness in Adults: The Netherlands Twin Register Study." Behavior Genetics 35:745-52.

Bouchard, C., A. Tremblay, J. Depres, A. Nadeau, P. J. Lupien, G. Theriault, J. Dussault, S. Moorjani, S. Pinnault, and G. Fournier. 1990. "The Response to Longterm Overfeeding in Identical Twins." New England Journal of Medicine 322: $1477-82$.

Bouchard, Thomas J., Nancy L. Segal, Auke Tellegen, Matt McGue, Margaret Keyes, and Robert F. Krueger. 2004. "Genetic Influence on Social Attitudes: Another 


\section{American Journal of Sociology}

Challenge to Psychology from Behavior Genetics." Pp. 89-104 in Behavior Genetic Principles: Development, Personality, and Psychopathology, edited by Lisabeth F. DiLalla. Washington, D.C.: American Psychological Association Press.

Boudon, Raymond. 2003. "Beyond Rational Choice Theory." Annual Review of Sociology 29:1-21.

Bradshaw, Matt. 2007. "Genetic Influences on Religious Involvement: Are They the Indirect Byproducts of Predispositions toward Social Interaction?” Paper presented at the annual meeting of the Society for the Scientific Study of Religion, Tampa, Fla.

Button, Tanya M. M., Jane Scourfield, Neilson Martin, Shaun Purcell, and Peter McGuffin. 2005. "Family Dysfunction Interacts with Genes in the Causation of Antisocial Symptoms." Behavior Genetics 35:115-20.

Card, David. 1999. "The Causal Effect of Education on Earnings." Pp. 1801-63 in Handbook of Labor Economics, , vol. 3, edited by Orley Ashenfelter and David Card. Amsterdam: Elsevier Science.

Caspi, Avshalom, Daryl J. Bem, and Glen H. Elder. 1989. "Continuities and Consequences of Interactional Styles across the Life Course." Journal of Personality $57: 375-406$

Caspi, Avshalom, Joseph McClay, Terri E. Moffitt, Jonathan Mill, Judy Martin, Ian W. Craig, Alan Taylor, and Richie Poulton. 2002. "Role of Genotype in the Cycle of Violence in Maltreated Children.” Science 297:851-54.

Caspi, Avshalom, Karen Sugden, Terri E. Moffitt, Alan Taylor, Ian W. Craig, HonaLee Harrington, Joseph McClay, Jonathan Mill, Judy Martin, Antony Braithwaite, and Richie Poulton. 2003. "Influence of Life Stress on Depression: Moderation by a Polymorphism in the 5-HTT Gene." Science 301:386-89.

Christakis, Nicholas A., and James H. Fowler. 2007. "The Spread of Obesity in a Large Social Network over 32 Years." New England Journal of Medicine 357:370-79.

Clark, Gregory. 2007. A Farewell to Alms: A Brief Economic History of the World. Princeton, N.J.: Princeton University Press.

Clausson, Britt, Paul Lichtenstein, and Sven Cnattingius. 2000. "Genetic Influence on Birthweight and Gestational Length Determined by Studies in Offspring of Twins." British Journal of Obstetrics and Gynecology 107:375-81.

Coleman, James S. 1986. "Social Theory, Social Research, and a Theory of Action." American Journal of Sociology 91:1309-35.

- 1990. Foundations of Social Theory. Cambridge, Mass.: Harvard University Press.

Collins, Francis S. 2004. "The Case for a Prospective Cohort Study of Genes and Environment." Nature 429:475-77.

Collins, John, Ned Hall, and L. A. Paul. 2004. Causation and Counterfactuals. Cambridge, Mass.: MIT Press.

Collins, Randall. 2004. Interaction Ritual Chains. Princeton, N.J.: Princeton University Press.

Coolidge, Frederick L., Linda L. Thede, and Susan E. Young. 2002. "The Heritability of Gender Identity Disorder in a Child and Adolescent Twin Sample." Journal of Autism and Development Disorders 37:847-54.

Devlin, Bernie, Michael Daniels, and Kathryn Roeder. 1997. "The Heritability of IQ." Nature 388:468-71.

Dick, Danielle M., and Laura J. Bierut. 2006. "The Genetics of Alcohol Dependence." Current Psychiatry Reports 8:151-57.

DiLalla, Lisabeth F., Jerome Kagan, and J. S. Reznick. 1994. "Genetic Etiology of Behavioral Inhibition among 2-Year-Old Children." Infant Behavior and Development 17:405-12.

DiMaggio, Paul. 1997. "Culture and Cognition.” Annual Review of Sociology 23:263-87. 
DiMaggio, Paul, John Evans, and Bethany Bryson. 1996. "Have Americans' Social Attitudes Become More Polarized?" American Journal of Sociology 102:690-755.

DiPrete, Thomas A., and Gregory M. Eirich. 2006. "Cumulative Advantage as a Mechanism for Inequality: A Review of Theoretical and Empirical Developments." Annual Review of Sociology 32:271-97.

Dunne, M. P., N. G. Martin, D. J. Statham, W. S. Slutske, S. H. Dinwiddie, K. K. Bucholz, P. A. F. Madden, and A. C. Heath. 1997. "Genetic and Environmental Contributions to Variance in Age at First Sexual Intercourse." Psychological Science 8:211-16.

Duster, Troy. 2006. "Comparative Perspectives and Competing Explanations: Taking on the Newly Configured Reductionist Challenge to Sociology." American Sociological Review 71:1-15.

Elder, Glen H., and Angela M. O'Rand. 1995. "Adult Lives in a Changing Society." Pp. 452-75 in Sociological Perspectives on Social Psychology, edited by K. S. Cook, G. A. Fine, and J. S. House. Needham Heights, Mass.: Allyn \& Bacon.

Ellis, Bruce J. 1992. "The Evolution of Sexual Attraction: Evaluative Mechanisms in Women." Pp. 267-88 in The Adapted Mind: Evolutionary Psychology and the Generation of Culture, edited by Jerome Barkow, Leda Cosmides, and John Tooby. Oxford: Oxford University Press.

Elster, Jon. 2007. Explaining Social Behavior: More Nuts and Bolts for the Social Sciences. Cambridge: Cambridge University Press.

Fischer, Claude S., Michael Hout, Martín Sánchez Jankowski, Samuel R. Lucas, Ann Swidler, and Kim Voss. 1996. Inequality by Design: Cracking the Bell Curve Myth. Princeton, N.J.: Princeton University Press.

Flint, Jonathan. 2000. "Genetic Influences on Emotionality." Pp. 431-57 in Genetic Influences on Neural and Behavioral Functions, edited by D. W. Pfaff, W. H. Berrettini, T. H. Joh, and S. C. Maxson. Boca Raton, Fla.: CRC Press.

Florez, Jose C., Joel Hirschhorn, and David Altshuler. 2003. "The Inherited Basis of Diabetes Mellitus: Implications for the Genetic Analysis of Complex Traits." Annual Review of Genomics and Human Genetics 4:257-91.

Fowler, James H., Laura A. Baker, and Christopher T. Dawes. 2008. "Genetic Variation in Political Participation.” American Political Science Review 102:233-48.

Frederick, Shane, George Loewenstein, and Ted O'Donoghue. 2002. "Time Discounting and Time Preference: A Critical Review." Journal of Economic Literature 40: 351-401.

Freese, Jeremy. 2006. "The Analysis of Variance and the Social Complexities of Genetic Causation." International Journal of Epidemiology 35:534-36.

- In press. "Preferences and the Explanation of Social Action." In Oxford Handbook of Analytic Sociology, edited by Peter Hedström and Peter Bearman. New York: Oxford University Press.

Freese, Jeremy, Jui-Chung Allen Li, and Lisa D. Wade. 2003. "The Potential Relevances of Biology to Social Inquiry." Annual Review of Sociology 29:233-56.

Freese, Jeremy, and Brian Powell. 1999. "Sociobiology, Status, and Parental Investment in Sons and Daughters: Testing the Trivers-Willard Hypothesis." American Journal of Sociology 106:1704-43.

Garfinkel, Alan. 1981. Forms of Explanation: Rethinking the Questions in Social Theory. New Haven, Conn.: Yale University Press.

Goldberger, Arthur S. 1979. "Heritability." Economica 46:327-47.

Goldthorpe, John H. 2000. On Sociology: Numbers, Narratives, and the Integration of Research and Theory. Oxford: Oxford University Press.

Gruenberg, Barry. 1980. "The Happy Worker: An Analysis of Educational and Occupational Differences in Determinants of Job Satisfaction." American Journal of Sociology 86:247-71. 


\section{American Journal of Sociology}

Guo, Guang, and Elizabeth Stearns. 2002. "The Social Influences on the Realization of Genetic Potential for Intellectual Development." Social Forces 80:881-910.

Hall, Ned. 2004. "Two Concepts of Causation." Pp. 181-203 in Causation and Counterfactuals, edited by John Collins, Ned Hall, and L. A. Paul. Cambridge, Mass.: MIT Press.

Heckman, James J. 2005. "The Scientific Model of Causality.” Sociological Methodology 35:1-98.

Hedström, Peter. 2005. Dissecting the Social: On the Principles of Analytical Sociology. Cambridge: Cambridge University Press.

Hedström, Peter, and Richard Swedberg. 1998. "Social Mechanisms.” Pp. 1-30 in Social Mechanisms, edited by Peter Hedström and Richard Swedberg. Cambridge: Cambridge University Press.

Hersch, Joni. 2006. "Skin Tone Effects among African Americans: Perceptions and Reality." American Economic Review 96 (2): 251-55.

Hettema, John M., Michael C. Neale, and Kenneth S. Kendler. 1995. "Physical Similarity and the Equal-Environment Assumption in Twin Studies of Psychiatric Disorders." Behavior Genetics 25:327-35.

Holland, Paul. 1986. "Statistics and Causal Inference." Journal of the American Statistical Association 81:945-60.

Huber, Joan, and Glenna D. Spitze. 1980. "Considering Divorce: An Expansion of Becker's Theory of Marital Instability." American Journal of Sociology 86:75-89.

Hudziak, James J., Toos C. E. M. van Beijsterveldt, Meike Bartels, Marjolein J. H. Rietveld, David C. Rettew, Eske M. Derks, and Dorret I. Boomsma. 2003. "Individual Differences in Aggression: Genetic Analyses by Age, Gender, and Informant in 3-, 7-, and 10-Year-Old Dutch Twins." Behavior Genetics 33:575-89.

Ilies, Remus, Megan Gerhardt, and Huy Le. 2004. "Individual Differences in Leadership Emergence: Integrating Meta-analytic Findings and Behavioral Genetics Estimates." International Journal of Selection and Assessment 12:207-19.

Jensen, Arthur R. 1969. "How Much Can We Boost IQ and Scholastic Achievement?" Harvard Educational Review 39:1-123.

Jocklin, Victor, Matt McGue, and David Lykken. 1996. "Personality and Divorce: A Genetic Analysis." Journal of Personality and Social Psychology 71:288-99.

Johnston, T. D., and L. Edwards. 2002. "Genes, Interactions, and the Development of Behavior." Psychological Review 109:26-34.

Kato, Kenji, and Nancy L. Pedersen. 2005. "Personality and Coping: A Study of Twins Reared Apart and Twins Reared Together." Behavior Genetics 35 (2): 147-58.

Kendler, Kenneth S., Margaret Gatz, Charles O. Gardner, and Nancy L. Pedersen. 2006. "A Swedish National Twin Study of Lifetime Major Depression." American Journal of Psychiatry 163:109-14.

Kendler, Kenneth S., Michael C. Neale, Ronald C. Kessler, Andrew C. Heath, and Lindon J. Eaves. 1993. "A Test of the Equal-Environment Assumption in Twin Studies of Psychiatric Illness." Behavioral Genetics 23:21-27.

Keski-Rahkonen, Anna, Richard J. Viken, Jaakko Kaprio, Aila Rissanen, and Richard J. Rose. 2004. "Genetic and Environmental Factors in Breakfast-Eating Patterns." Behavior Genetics 34 (5): 503-14.

Kohn, Melvin L. 1976. "Occupational Structure and Alienation." American Journal of Sociology 82:111-30.

Kohn, Melvin L., and Carmi Schooler. 1978. "The Reciprocal Effects of the Substantive Complexity of Work and Intellectual Flexibility: A Longitudinal Assessment." American Journal of Sociology 84:24-52.

Kreek, Mary Jeanne, David A. Nielsen, Eduardo R. Butelman, and K. Steven LaForge. 2005. "Genetic Influences on Impulsivity, Risk Taking, Stress Responsivity, and Vulnerability to Drug Abuse and Addiction." Nature Neuroscience 8:1450-57. 
Lewontin, Richard C. 1974. "The Analysis of Variance and the Analysis of Causes." American Journal of Human Genetics 26:400-411.

Li, Ming D. 2003. "The Genetics of Smoking-Related Behavior: A Brief Review." American Journal of the Medical Sciences 326:168-73.

Lieberson, Stanley. 1985. Making It Count: The Improvement of Social Research and Theory. Berkeley and Los Angeles: University of California Press.

Loehlin, John C. 1992. Genes and Environment in Personality Development. Newbury Park, Calif.: Sage.

Luciano, Michelle, Mark A. Wainwright, Margaret J. Wright, and Nicholas G. Martin. 2006. "The Heritability of Conscientiousness Facets and Their Relationship to IQ and Academic Achievement." Personality and Individual Differences 40:1189-99.

Macgregor, Stuart, Belinda Cornes, Nicholas Martin, and Peter Visscher. 2006. "Bias, Precision and Heritability of Self-Reported and Clinically Measured Height in Australian Twins." Human Genetics 120:571-80.

Machamer, Peter, Lindley Darden, and Carl F. Craver. 2000. "Thinking about Mechanisms." Philosophy of Science 67:1-25.

Maes, H. H., Michael C. Neale, and Lindon J. Eaves. 1997. "Genetic and Environmental Factors in Relative Body Weight and Human Adiposity." Behavior Genetics 27:325-51.

Manza, Jeff, and Clem Brooks. 1998. "The Gender Gap in U.S. Presidential Elections: When? Why? Implications?" American Journal of Sociology 103:1235-66.

McCabe, Linda L., and Edward R. B. McCabe. 2008. DNA: Promise and Peril. Berkeley and Los Angeles: University of California Press.

McCrae, Robert R., and Paul T. Costa. 2003. Personality in Adulthood, Second Edition: A Five-Factor Perspective. New York: Guilford Press.

McGue, Matt, T. J. Bouchard, W. G. Iacono, and David T. Lykken. 1993. "Behavioral Genetics of Cognitive Ability: A Life-Span Perspective." Pp. 59-76 in Nature, Nurture, and Psychology, edited by R. Plomin and G. E. McClearn. Washington, D.C.: American Psychological Association.

McGue, Matt, and David T. Lykken. 1992. "Genetic Influence on Risk of Divorce." Psychological Science 3:368-73.

McGuire, Shirley, Jenae M. Neiderhiser, David Reiss, E. Mavis Hetherington, and Robert Plomin. 1994. "Genetic and Environmental Influences on Perceptions of SelfWorth and Competence in Adolescence: A Study of Twins, Full Siblings, and Stepsiblings." Child Development 65:785-99.

Meier, Ann M. 2007. "Adolescent First Sex and Subsequent Mental Health.” American Journal of Sociology 112:1811-47.

Merrill, Kari A., Joseph E. Steinmetz, Richard J. Viken, and Richard J. Rose. 1999. "Genetic Influences on Human Conditionability: A Twin Study of the Conditioned Eyeblink Response." Behavior Genetics 29:95-102.

Miller, Alan S., and Satoshi Kanazawa. 2001. Order by Accident: The Origins and Consequences of Conformity in Contemporary Japan. Boulder, Colo.: Westview Press.

Moffitt, Terrie E., Avshalom Caspi, and Michael Rutter. 2005. "Strategy for Investigating Interactions between Measured Genes and Measured Environments." Archives of General Psychiatry 62:473-81.

Morgan, Stephen L., and Christopher Winship. 2007. Counterfactuals and Causal Inference: Methods and Principles for Social Research. Cambridge: Cambridge University Press.

Morris, Corey, Aimee Shen, Khadija Pierce, and Jonathan Beckwith. 2007. "Deconstructing Violence." GeneWatch 20: n.p. http://www.gene-watch.org/ genewatch/articles/20-2Beckwith.html

Nederkoorn, Chantal, Caroline Braet, and Yvonne Van Eijs. 2006. "Why Obese Children Cannot Resist Food: The Role of Impulsivity." Eating Behaviors 7:315-22.

Nielsen, François. 2006. "Achievement and Ascription in Educational Attainment: 


\section{American Journal of Sociology}

Genetic and Environmental Influences on Adolescent Schooling." Social Forces 85: 193-216.

Olson, James M., Philip A. Vernon, Julie Aitken Harris, and Kerry L. Jang. 2001. "The Heritability of Attitudes: A Study of Twins." Journal of Personality and Social Psychology 80:845-60.

Pedersen, Nancy, Robert Plomin, Gerald E. McClearn, and Lars Friberg. 1988. "Neuroticism, Extraversion, and Related Traits in Adult Twins Reared Apart and Reared Together." Journal of Personality and Social Psychology 55:950-57.

Pérusse, Daniel, Michael C. Neale, Andrew C. Heath, and Lindon J. Eaves. 1994. "Human Parental Behavior: Evidence for Genetic Influence and Potential Implication for Gene-Culture Transmission." Behavior Genetics 24:327-35.

Plomin, Robert, John C. DeFries, and John C. Loehlin. 1977. "Genotype-Environment Interaction and Correlation in the Analysis of Human Behavior." Psychological Bulletin 84:309-22.

Plomin, Robert, John C. DeFries, Gerald E. McClearn, and Peter McGuffin. 2001. Behavioral Genetics, 4th ed. New York: Worth Publishers and W. H. Freeman.

Plomin, Robert, Michael J. Owen, and Peter McGuffin. 1994. "The Genetic Basis of Complex Human Behaviors." Science 264:1733-39.

Prescott, Carol A., Pamela A. F. Madden, and Michael C. Stallings. 2006. "Challenges in Genetic Studies of the Etiology of Substance Use and Substance Use Disorders." Behavior Genetics 36:473-82.

Quillian, Lincoln, and Devah Pager. 2001. "Black Neighbors, Higher Crime? The Role of Racial Stereotypes in Evaluations of Neighborhood Crime." American Journal of Sociology 107:717-67.

Robinson, JoAnn L., Jerome Kagan, J. Steven Reznick, and Robin P. Corley. 1992. "The Heritability of Inhibited and Uninhibited Behavior: A Twin Study." Developmental Psychology 28:1030-37.

Rowe, David C. 1994. The Limits of Family Influence: Genes, Experience, and Behavior. New York: Guilford. 2002. Biology and Crime. Los Angeles: Roxbury.

Rushton, J. Philippe, David W. Fulker, Michael C. Neale, David K. B. Nias, and Hans J. Eysenck. 1986. "Altruism and Aggression: The Heritability of Individual Differences." Journal of Personality and Social Psychology 50:1192-98.

Rutter, Michael, Judy Dunn, Robert Plomin, Emily Simonoff, Andrew Pickles, Barbara Maughan, John Ormel, Joanne Meyer, and Lindon J. Eaves. 1997. "Integrating Nature and Nurture: Implications of Person-Environment Correlations and Interactions for Developmental Psychopathology." Development and Psychopathology 9:335-64.

Rutter, Michael, Robin Murray, Andrew Pickles, and Lindon J. Eaves. 2001. "Testing Hypotheses on Specific Environmental Causal Effects on Behavior." Psychological Bulletin 127:291-324.

Sampson, Robert J., and John H. Laub. 1993. Crime in the Making: Pathways and Turning Points through Life. Cambridge, Mass.: Harvard University Press.

Samuelson, Paul A. 1947. Foundations of Economic Analysis. Cambridge, Mass.: Harvard University Press.

Sankar, Pamela, Mildred K. Cho, Celeste M. Condit, Linda M. Hunt, Barbara Koenig, Patrick Marshall, Sandra Soo-Jin Lee, and Paul Spicer. 2004. "Genetic Research and Health Disparities." Journal of the American Medical Association 291:2985-89.

Schaffner, Kenneth F. 2006. "Behavior: Its Nature and Nurture, Part 1." In Wrestling with Behavioral Genetics: Science, Ethics, and Public Conversation, edited by Erik Parens, Audrey R. Chapman, and Nancy Press. Baltimore: Johns Hopkins University Press.

Scourfield, Jane, Neilson Martin, Glyn Lewis, and Peter McGuffin. 1999. "Heritability 
of Social Cognitive Skills in Children and Adolescents." British Journal of Psychiatry 175:559-64.

Sewell, William H., and Robert M. Hauser. 1975. Education, Occupation, and Earnings: Achievement in the Early Career. New York: Academic Press.

Shanahan, Michael J., and Scott M. Hofer. 2005. "Social Context in Gene-Environment Interaction: Retrospect and Prospect." Journals of Gerontology, ser. B 60:65-76.

Snyder, Mark, Elizabeth D. Tanke, and Ellen Berscheid. 1977. "Social Perception and Interpersonal Behavior: On the Self-Fulfilling Nature of Social Stereotypes.” Journal of Personality and Social Psychology 35:656-66.

Sternberg, Robert J., and James C. Kaufman. 1998. "Human Abilities.” Annual Review of Psychology 49:479-502.

Stigler, George J., and Gary S. Becker. 1977. "De Gustibus Non Est Disputandum." American Economic Review 67:76-90.

Stoel, Reinoud D., Eco J. C. De Geus, and Dorret I. Boomsma. 2006. "Genetic Analysis of Sensation Seeking with an Extended Twin Design." Behavior Genetics 35:229-37.

Tesser, Abraham. 1993. "The Importance of Heritability in Psychological Research: The Case of Attitudes." Psychological Review 100:129-42.

Thompson, Lee Anne, Douglas K. Detterman, and Robert Plomin. 1993. "Differences in Heritability across Groups Differing in Ability, Revisited." Behavior Genetics 23: 331-36.

Tozzi, Frederica, Stephen H. Aggen, Benjamin M. Neale, Charles B. Anderson, Suzanne E. Mazzeo, Michael C. Neale, and Cynthia M. Bulik. 2004. "The Structure of Perfectionism: A Twin Study." Behavior Genetics 34:483-94.

Truett, Kim R., Lindon J. Eaves, Ellen E. Walters, Andrew C. Heath, John K. Hewitt, and Joanne M. Meyer. 1994. "A Model System for Analysis of Family Resemblance in Extended Kinships of Twins." Behavior Genetics 24:35-49.

Turkheimer, Eric. 2000. "Three Laws of Behavior Genetics and What They Mean." Current Directions in Psychological Science 9:160-64.

. 2004. "Spinach and Ice Cream: Why Social Science Is So Difficult." Pp. 161-89 in Behavior Genetics Principles: Perspectives in Development, Personality, and Psychopathology, edited by Lisabeth F. Dilalla and Irving I. Gottesman. Washington, D.C.: American Psychological Association.

Turkheimer, Eric, Andreana Haley, Mary Waldron, Brian D'Onofrio, and Irving I. Gottesman. 2003. "Socioeconomic Status Modifies Heritability of IQ in Young Children." Psychological Science 14:623-28.

Udry, J. Richard. 1995. "Sociology and Biology: What Biology Do Sociologists Need to Know?" Social Forces 73:1267-78.

Wahlsten, Douglas. 1990. "Insensitivity of the Analysis of Variance to HeredityEnvironment Interactions." Behavioral and Brain Sciences 13:109-61.

Webster, Christopher D., and Margaret A. Jackson, eds. 1997. Impulsivity: Theory, Assessment, and Treatment. New York: Guilford.

Widaman, Keith F., and Colleen Azen. 2003. "Relation of Prenatal Phenylalanine Exposure to Infant and Childhood Cognitive Outcomes: Results from the International Maternal PKU Collaborative Study." Pediatrics 112:1537-43.

Woodward, James. 2003. Making Things Happen: A Theory of Causal Explanation. Oxford: Oxford University Press.

Wylie, Ruth. 1979. The Self-Concept. Lincoln: University of Nebraska Press. 